\title{
The Communication Methods in English Classroom for Indonesian Deaf Students
}

\author{
Rohmani Nur Indah \\ Universitas Islam Negeri Maulana Malik Ibrahim Malang, Indonesia \\ Chanastalia \\ Universitas Islam Negeri Maulana Malik Ibrahim Malang, Indonesia
}

\begin{abstract}
Deaf students can only use their visual to acquire their first language namely sign language. Mostly hearing people do not understand sign language therefore deaf students use lip-reading to communicate with them. However, lip-reading especially in foreign language not always works because some phonemes are not visible in the lips. This study investigates the communication method of deaf students in learning English as foreign language. It observes the classroom interaction in an Indonesian special school for deaf students. The result shows that deaf students use four communication methods such as sign language, lip-reading, fingerspelling, and Tadoma. The result also shows that deaf students understand words or utterances which are familiar for them. However, deaf students find difficulties in pronouncing words or utterances. They tend to pronounce in Bahasa Indonesia. Therefore, it is recommended that teacher and hearing parents of deaf child must update with the latest technology or material for deaf students learning.
\end{abstract}

Index Terms — deaf students, English as foreign language, lip-reading

\section{INTRODUCTION}

Deaf students do not learn English or Bahasa Indonesia as their first language. Their first language is sign language (Humphries et al., 2014). It becomes difficult when deaf students are communicating with hearing peers who do not understand about sign language at all. Therefore, deaf students need several communication methods that enable them to communicate with their hearing peers in daily conversation.

Since deaf students have hearing impairment, either deaf or hard-of-hearing (Hernawati, 2007), they have several barriers in acquiring or learning language. The first barrier is late language acquisition. Mostly deaf students were born and raised in hearing family. Their families are less proficient in signing while linguists consider that sign language is the best language for deaf child (Mellon et al., 2015).

The second barrier concerns with the difference between spoken and sign language. Spoken language is arbitrary while sign language is iconic. Yule (2010) stated that arbitrariness is "the relationship between linguistic signs and objects in the world" (p.12). It means how the world looks like does not refer the meaning of the word. This arbitrariness does not belong to sign language. Sign language is iconic. Iconic means that when we are signing, the sign is similar or associated with the meaning. For instance, when a deaf child wants to go to the bathroom, he will directly close his nose to refer the word 'smell' and it associate with bathroom (Meier, 1991).

The third barrier is poor in phonological information. Deaf students cannot differentiate phoneme which has the same lip movement such as /f/ and /b/ (Liben, 1978). The last barrier is lack of family and education support. In rural area, many parents cannot afford hearing aid since the price is quite expensive and it makes the deaf child very difficult to learn spoken language (Szymanski et al., 2013). School with less facilities and inappropriate curriculum makes the deaf students difficult to follow the school's program (UNESCO, 2000).

Teaching spoken language for deaf students can be mediated by several communication methods, one of which is lipreading. It means understanding what people say by watching the movement of the lips. The term lip-reading is changed with speech-reading. Speech-reading tends to use lips and body movement, while lip-reading only uses the lips movement (Victorian Deaf Society, 2010). Since mostly hearing people do not understand sign language, lip-reading must be taught to deaf students to make them easier in communicating with hearing world.

In general deaf students have different way in learning language compared to hearing students. The first difference is deaf students use sign language as their first language while hearing students use their native language as their first language (Humphries, et al., 2014). The second difference is deaf students have different stages in acquiring language. In babbling stage, deaf infants use gesture and syllabic manual babbling while hearing infants use spoken language like 'ba-ba-ba' or 'ma-ma-ma' (Carroll, 2008). The last difference is deaf students have different literacy levels. It is because the late language acquisition as the obstacle for deaf student in learning reading. At the age of 13-14 years old, hearing students reach seventh to eighth reading levels while deaf students can only reach third to fourth reading levels (Bowe, 1998). 
Dealing with the barriers, Mellon et al. (2015) showed the importance of using and learning sign language for deaf children. There are several advantages and difficulties in using sign language. It helps teacher to communicate effectively in class by using several communication techniques such as emblem, illustrator, affect display, regulator and adaptor (Wulansari, 2012). It also supports the process of language acquisition of deaf children (Humphries et al., 2014). These studies concern with first language acquisition for deaf students. Meanwhile, this research concerns with the communication methods employed in the context of foreign language learning.

\section{LITERATURE REVIEW}

Every deaf person has different type of deafness based on the intensity sounds loudness (decibels-dB). The first is slight or mild (26-40dB) meaning trouble in hearing sounds from certain distance and speech against noisy place. The second is moderate $(41-60 \mathrm{~dB})$ that is problem in hearing regular speech even in close distance. The third is severe (61$80 \mathrm{~dB}$ ) making the person can only hear loud or very loud sound. The last is profound (over $81 \mathrm{~dB}$ ) that is receiving loud sounds as a vibration (WHO, 2016).

Deafness in children is influenced by several aspects. The first is the age of hearing loss. Children who get their hearing loss many years later will more likely easier to develop their language because, some of them had already know oral communication and have better literacy (UNESCO, 2000). The second is degree of hearing loss. Children with mild or moderate hearing loss can be helped by using hearing aid. However, if the children cannot hear at all (deaf), it will be more difficult to learn oral language (Deaf Children Australia, 2012). The last is parents hearing status. A deaf mother of deaf child will directly communicate with her child using sign language while hearing mother still left behind because she needs to learn sign language first (Marschark, 2001).

Having hearing impairment makes the deaf children use several communication methods. The most common method is sign language. It is based on three components, the place where the sign is made, the shape and angle of the hand(s) and the movement of the hand(s) (Field, 2004, p. 264). Sign language represents each word associated with its meaning. In producing sign language, there are four important keys to make it as understandable sign language. Those are shape, orientation, location, and movement. Shape how the hands form to show a particular word or sentence. For instance flat hand, fist hand, or cupped hand. Orientation refers to how the hand 'palm up' or 'palm down'. Location refers the position of the hand movement, whether it is in front of our chest or upper body. In speech language, this is similar with place of articulation. Movement refers to how the hand changes the position. For instance, the hands move from chest up to head (Yule, 2010).

The origin of the sign language came from French Sign Language (FSL). It was developed by Lauren Clerc. Then FSL came to the United States as American Sign Language (ASL) and it was brought by Thomas Gallaudet, who was well known as the founder Gallaudet University (Bellugi \& Klima, 1978). Another sign language is British Sign Language. In Indonesia, there is also sign language called Bahasa Isyarat Indonesia (BISINDO).

Similar to sign language, fingerspelling is a signing with one or both hands. Fingerspelling tends to spell a letter by using fingers. It is used to spell a name or country (Steinberg \& Sciarini, 2006). The spelled alphabet with conjunction to speech form called Rochester Method. It is very useful to young deaf children which will have advantage in better oral skills (Moores, 1997). Usually, deaf children are using both sign language and finger-spelling. For instance, when deaf child try to say 'my name is Anne', she will use sign language in my name is, and Anne with finger-spelling.

Another method is lip-reading. It is originally an ability to 'read' what people says by seeing the movement of the lips, tongue and jaw. However, it is widen with reading of the body and face movement called speech-reading (Victorian Deaf Society, 2010). Lip-reading is mostly used for hearing people who do not understand sign language. Therefore, mostly deaf people will communicate use lip-reading in certain language, Indonesian language for instance. Lip-reading has different rules. In Jena and Kenzie's method, lip-reading also uses facial expression and body movement. However, in Bruhn's method lip-reading theory only involves lips movement of the speaker. In this method, phonemes are categorized into two class of consonants based on the visibility on the lips (Bruhn, 1915). The consonants in Table 1 are more visible than those in Table 2 as shown below:

TABLE 1.

CLASS I OF CONSONANTS

CLASS I OF CONSONANTS
\begin{tabular}{|l|l|}
\hline Consonants & Phonetic symbol \\
\hline $\mathrm{f}$ & $\mathrm{F}$ \\
\hline $\mathrm{v}$ & $\mathrm{V}$ \\
\hline $\mathrm{s}$ & $\mathrm{S}$ \\
\hline $\mathrm{z}$ & 3 \\
\hline $\mathrm{sh}$ & S \\
\hline $\mathrm{m}$ & $\mathrm{M}$ \\
\hline $\mathrm{b}$ & $\mathrm{B}$ \\
\hline $\mathrm{p}$ & $\mathrm{P}$ \\
\hline $\mathrm{w}$ & $\mathrm{W}$ \\
\hline th & $\theta$ and $~$ \\
\hline
\end{tabular}


TABLE 2.

CLASS II OF CONSONANTS

\begin{tabular}{|l|l|}
\hline Consonants & Phonetic symbol \\
\hline $\mathrm{k}$ & $\mathrm{K}$ \\
\hline $\mathrm{g}$ & $\mathrm{d}$ \\
\hline $\mathrm{ch}$ & $\mathrm{t}$ \\
\hline $\mathrm{d}$ & $\mathrm{D}$ \\
\hline $\mathrm{t}$ & $\mathrm{T}$ \\
\hline $\mathrm{h}$ & $\mathrm{H}$ \\
\hline $\mathrm{l}$ & $\mathrm{L}$ \\
\hline $\mathrm{n}$ & $\mathrm{N}$ \\
\hline $\mathrm{r}$ & $\mathrm{R}$ \\
\hline th & $\theta$ and \\
\hline
\end{tabular}

There are several rules regarding each class of consonant. Those are how to pronounce $/ \mathrm{h} / \mathrm{before}$ a vowel, /r/ before and after a vowel, /r/ after /f/, /b/, /p/, /th/, /r/ after /c/ and /g/ and others. These rules have different shape of the lips to recognize the lip-reader to understand what the speaker said. For instance, the phoneme /w/ or /wh/, has the same way in pronouncing diphthong /ōō/. In this case, the phoneme $/ \mathrm{r} /$ is difficult to recognize. In Bruhn's method, there are several rules regards to the pronunciation. The $/ \mathrm{r} /$ before a vowel is the forward of the lips, in differentiate those $/ \mathrm{r} /$ before a vowel, for example rä, rō, rōō, rā, rē, röû, rï, röı̆, râ (Bruhn, 1915, p.43).

\section{METHOD}

The goal of this study is to describe the communication method of deaf students during English course. It employs case study approach which focuses on English classroom in a special junior high school for students with deafness in Malang, East Java, Indonesia. It took English class grade 7th and 9th in conducting non-participant observation supported with other instruments such as field note, interview, video recording, and documentation. During the English classroom activities, the observed communication is related to the deaf students' communication method, their ability and difficulty in learning English. The observed communication methods are those involved in students' ability in pronunciation, understanding and answering teacher's questions. The analysis is done to identify the pattern of communication among deaf students and their English teacher. It also covers the identification of the difficulties faced by deaf students based on Bruhn lip-reading theory (1915). This stage analyze several words, phrases, or sentences that pronounced using lip-reading and the reason why the deaf students difficult to pronounce and understand. The last stage is drawing conclusion on how deaf students communicate using several communication methods and their difficulties during English class.

\section{RESUlts}

All of the students in the observed special school suffer from hearing problem either moderate or severe because the students cannot hear in noisy place and regular conversation. In communicating and learning English as foreign language (EFL), the deaf students use sign language, lip-reading, fingerspelling and Tadoma. In SMPLB-B YPTB, all of the deaf students use BISINDO (Bahasa Isyarat Indonesia) as the main communication device. This sign language is used for communicating either with the teacher or their peers. However, both lip-reading and fingerspelling become the addition communication device to make the utterances clearer and to avoid misunderstanding. The deaf students have good skill in lip-reading for Bahasa Indonesia. Moreover, the deaf students can communicate with hearing people by only using lip-reading in Bahasa Indonesia. The last communication device is Tadoma. Tadoma is only used when the teacher teaches about how to pronounce certain words. This method is actually used for deaf-blind people. However, it can also be used for deaf students.

In using those communication methods, make the deaf students have several abilities and difficulties in learning English as foreign language. The abilities are summarized in Table 3. 
TABLE 3.

ABILITIES IN COMMUNICATION

\begin{tabular}{|c|c|}
\hline Abilities & Code \\
\hline Pronouncing GOOD MORNING*** & A1 \\
\hline Answering WHAT'S YOUR NAME?*** & $\mathrm{A} 2$ \\
\hline Understanding in using plural or single form $* * *$ & A3 \\
\hline Pronouncing SHOPPING*** & A4 \\
\hline Pronouncing INTERNET $* * *$ & A5 \\
\hline Pronouncing SOUP*** & A6 \\
\hline Pronouncing numbers** & A7 \\
\hline Understanding FRESH MILK, CARROT, EGGS**** & A8 \\
\hline Pronouncing ALWAYS*** & A9 \\
\hline Pronouncing DO $* * *$ & A10 \\
\hline Pronouncing FRIEND**** & A11 \\
\hline Understanding PEN, PENCIL *** & A12 \\
\hline
\end{tabular}

In datum A1, The first letter of the first word [good] is /g/ included in class II of consonants (Bruhn, 1915, p. 23). All of the students understand [good morning] in lip-reading. The teacher repeats this phrase each meeting. Therefore, the students memorize how to pronounce and write correctly. Another reason is the inter-movement in the word [morning] pronunciation is similar to its written form. Inter-movement refers to the movement from one syllable to another such as in /mo:r-niy/. The more the two sounds which are to be connected differ in direction, the plainer this inter-movement will naturally appear (Bruhn, 1915, p. 6). This also happens in datum A2. The deaf students also understand several words that are familiar for them. In datum A4-A12, all of the deaf students understand the meaning of the words and its pronunciation. They understand how to pronounce the word because some of the words have the same pronunciation in Bahasa Indonesia. The words are mostly included in nouns.

TABLE 4.

DIFFICULTIES IN COMMUNICATION

\begin{tabular}{|l|l|}
\hline Abilities & Code \\
\hline Pronouncing STUDY*** & $\mathrm{D} 1$ \\
\hline Pronouncing EAT $* *$ & $\mathrm{D} 2$ \\
\hline Pronouncing RICE*** & $\mathrm{D} 3$ \\
\hline Understanding interrogative sentences $* * *$ & $\mathrm{D} 4$ \\
\hline Pronouncing HOUSE*** & $\mathrm{D} 5$ \\
\hline Pronouncing SOMETIMES*** & $\mathrm{D} 6$ \\
\hline Understanding BREAKFAST $* * *$ & $\mathrm{D} 7$ \\
\hline Pronouncing YOU** & $\mathrm{D} 8$ \\
\hline Pronouncing USUALLY** & $\mathrm{D} 9$ \\
\hline Understanding SEMESTER $* * *$ & $\mathrm{D} 10$ \\
\hline Understanding phrases $* * *$ & $\mathrm{D} 11$ \\
\hline Understanding grammatical order $* * *$ & $\mathrm{D} 12$ \\
\hline
\end{tabular}

Note: ***all students; **some students

However, deaf students have more difficulties than their abilities in case of learning English as foreign language. Most of the deaf students are difficult to pronounce word which has invisible lips movement (datum D1, D3, D5, D6, D10, D14, D17). In addition, the words which have different pronunciation with its written form are also difficult to pronounce (D1, D2, D3, D5, D6, D7, D8, D9, D10, D13, D14, D17). All of the students pronounce the word STUDY as

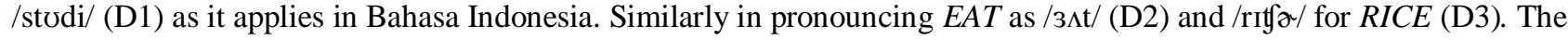
word HOUSE is pronounced /hous3/ (D5) and /som.tim3 s/ for SOMETIMES (D6). Pronouncing diphthong is also difficult in the word YOU that is pronounced /jaw/ (D8). Based on those findings, sign language is the best option for deaf students as their first language. Moreover, sign language must be taught to deaf children regardless they receive cochlear implants or not (Mellon et al., 2015). However, not all hearing people understand how to sign. This barrier makes the deaf students feel difficult in hearing society. Therefore, lip-reading is used to communicate as the addition communication method instead of sign language. Some deaf students understand what the hearing people say by only watch their lips movement. The speaker must use the language that is understood by the deaf students and avoid similar words.

\section{DISCUSSION}

\section{A. Deaf Students in Learning English as Foreign Language and Their Abilities}

The deaf students and the teacher use several communication methods in teaching and learning in English classroom. Sign language is used the most during teaching and learning in English classroom. The teacher and deaf students use sign language to communicate one another. They also use lip-reading to combine with the sign language for example "what's your name?", sign language in the word your and lip-reading for all words (datum A2). The aim of this combination is to make clear and concise communication among the speakers. 
Another communication method used by deaf students and the teacher is Tadoma and finger-spelling. Tadoma is rarely used because it is focused on pronunciation of words. Finger-spelling, as it named, is used to spell particular noun or name. In addition, finger-spelling is also used when there is a word that is difficult to pronounce and the deaf students or the teacher uses the first letter then pronounce the word.

Differ with finger-spelling which is often used by deaf students, Tadoma users are mostly deaf-blind students. The Tadoma user's hand placed over the face and neck to feel the vibration that emerge while producing spoken words or sentences (Reed, n.d). Since deaf-blind students cannot use their visual to communicate with others, they use their tactile sense as their main 'device' to communicate and learn language, for example a student cannot pronounce nine correctly and the teacher uses Tadoma method to correct and show how the right pronounciation (datum A7).

Tadoma method is not easy task for the users. The skilled Tadoma users must receive intensive and long-term training before they become successful users. Another reason is not every child has the same tactile sense. Therefore, they may have different reception in using Tadoma (Reed, n.d).

The result of this communication is many deaf students understand in several words and sentences in English classroom. Based on the findings, the deaf students are able to pronounce words where it has the same pronunciation way in Bahasa Indonesia. For example the words shopping, internet, soup, and pen (datum A4, A5, A6, A12). The deaf students do not find difficult as long as they are familiar with the words. For example, the words good morning, what's your name, numbers, always, do, and friend (datum A1, A2, A7, A9, A10, A11). Regardless the words have one or more syllables. However, mono-syllable is more difficult for lip-reading than many syllables (Bruhn, 1915).

In case of understanding vocabularies, the deaf students understand the words or phrases that are repeated in each meeting. For example, good morning, what's your name, and some numbers (datum A1, A2, A7). They also understand several vocabularies which familiar for them. For example, fresh milk, carrot, eggs and pen, pencil (datum A8, A12). However, these words or phrases have syllables which no more than four syllables.

Not all of these communication methods are used during peers' conversation. The deaf students use Bahasa Isyarat Indonesia (Indonesian Sign Languange) or BISINDO and lip-reading to communicate with their peers. Hearing people can speak with only use lip-reading with the deaf students. However, the speaker must speak the language that the deaf students understand. For instance, Bahasa Indonesia.

Based on those findings, sign language is the best option for deaf students as their first language. This language is supposed to be taught to deaf children regardless they receive cochlear implants or not (Mellon et al., 2015). In the early 1990, many researchers suggest that the use of cochlear implants for deaf children should be at the age of two years and in 2000 cochlear implant can be used by deaf children at the age of 12 months old (Humphries, et al., 2014). During the time before the deaf children wear the cochlear implants, this critical age must be filled with sign language as their first language.

However, not all hearing people understand how to sign. This barrier makes the deaf students feel difficult in hearing society. Therefore, lip-reading is used to communicate as the addition communication method instead of sign language. Some deaf students understand what the hearing people say by only watch their lips movement. The speaker must use the language that is understood by the deaf students and avoid similar words.

Even deaf students understand lip-reading in Bahasa Indonesia, in this case, using lip-reading in foreign class is very difficult to be applied. Regardless they use hearing aids or not, English is a new language for them. Using lip-reading in understanding foreign language such English is very difficult for deaf students. They understand half of the speaker's say while the rest is guessing (Doleżalova, 2013).

Sign language and lip-reading are not sufficient for deaf students. In foreign class, it is very hard to make the deaf students understand particular material with only using sign language and lip-reading. This problem is not only because the students have hearing problem, but also the teacher takes an important role for students' development. Regular teachers are not sufficient enough to teach deaf students even they are able to sign. They must receive special training in teaching deaf students in order to know what the student needs (Domagala-Zyśk, 2015).

Sending deaf students in mainstream school is not a good choice in case of learning foreign language. Since they have many hearing peers, it is difficult to follow the class' conversation. For deaf students, attending this kind of school in understanding the conversation is too fast for them. The other problem is every student has different pronunciation (Doleżalova, 2013).

Learning foreign language for deaf students is not an easy task. They already feel difficult in learning their first and second language, those are sign language and Bahasa Indonesia. Since both languages, Bahasa Indonesia and English are very different in case of modality, the deaf students were confused to pronounce or sign the words. In teaching deaf students, unfamiliar words, words look visually similar in print, and multi-syllabic words must be pronounced. The teacher also shows words which share the same sign such as technique, technology and technical (Gustafson, 2008).

\section{B. Deaf Students' Difficulties in Communicating Using Lip-reading}

The result of the language difference, English and Bahasa Indonesia, makes the deaf students have several difficulties in learning English as foreign language. Based on the findings, there are two kinds of difficulties faced by deaf students. Those are pronouncing words. For example pronouncing study, eat, rice, house, sometimes, you, usually, up, and comfortable (datum D1, D2, D3, D5, D6, D8, D9, D13, D14) and understanding the meaning of vocabularies. For example changing positive into interrogative sentences, breakfast, semester, verb phrases such take a bath, grammatical 
order such sweep the floor of the class, ruler, adjectives such clean, and sharpener (datum D4, D7, D10, D11, D12, D15, D16, D17). These two difficulties are mostly occurred in English classroom. In learning foreign language, deaf students often face several barriers such as unknown vocabulary, difficulty in pronunciation, oral comprehension, and so on (Moritz, 2016).

In case of understanding vocabularies, the deaf students are mostly found difficult in noun. For example the words eat, rice, house, breakfast, semester, ruler and sharpener (datum D2, D3, D5, D7, D10, D15, D17). They do not understand at all the meaning of those words in Bahasa Indonesia. Those words are not familiar for the deaf students and rarely used in each meeting or rarely used in daily life.

In case of pronouncing words, the deaf students have the same difficulties in mono-syllabic and many syllables words. They cannot lip-read several words that have invisible lips movement. They are difficult to recognize what the teacher's said. Even the teacher writes the words or phrases on the whiteboard, the deaf students still cannot pronounce correctly. For example, study, eat, rice, house, sometimes, you, usually, up, and comfortable (datum D1, D2, D3, D5, D6, D8, D9, D13, D14).

Even the deaf students cannot lip-reading in English, they understand lip-reading in Bahasa Indonesia. However, the speaker cannot speak as they speak with hearing students. The speaker must pay attention at several rules to speak without sign language to deaf students. The first rule is to speak slowly. It is because to make the deaf students can 'catch' each words and sentences that the speaker wants to say. The second rule is open the mouth widely. The speaker does not need to open the mouth too wide or too narrow. It is because the deaf students recognize the lips movement of the speaker. The last rule is avoiding similar words in case of pronounciation. The example of this rule in Bahasa Indonesia is "susah" and "suka". The speaker should avoid these words and change into another word with the same meaning but different pronunciation.

Regardless the deaf students use lip-reading or another communication technique, learning foreign language is a difficult task whether for the deaf students or the teacher. In Czech Republic, deaf students not only learn inside the class. Every year, the deaf students are learning English in The United States for three weeks. The aim of this outdoor class is to make the deaf students understand the native speaker and the origin of English itself (Doleżalova, 2013).

Another method that is used in teaching deaf students is class' condition. Since deaf students use their visual as their main communication device, the teacher arranges the desk into circle form so the deaf students are easy to pay attention on the speaker. Both teacher and deaf students must follow the rule in conversation in the class such as speak clearly, face directed to the peers or teacher, and avoid standing behind the window (Domagala-Zyśk, 2015).

Using picture in explaining vocabulary to deaf students is also a good choice since they use their visual as the main communication device. In each meeting, the deaf students must learn new vocabularies. Memorizing vocabularies using picture as the teaching device has better result than not using picture at all. Deaf students who learn vocabularies with picture have better performance than deaf students who do not use picture as learning device (Birinci, 2014).

In Norway, the teacher encourages the deaf students to learn foreign language by using foreign sign language. This method makes the deaf students confidence and believed that they have ability as hearing students do. Similar with studying in Czech Republic, sending the deaf students abroad are also has advantages to boost their language skill (Pritchard, 2013).

However, those methods do not always suitable for some deaf students. Therefore, teacher of deaf students must active and always looking for new material to enhance deaf students' comprehension in the class. Teacher for deaf students also need exchange ideas and guidance from other teacher to enrich their skill in teaching deaf students (Dotter, 2008).

Teaching deaf students using lip-reading is very difficult and not sufficient enough. Since their Bahasa Indonesia and English are very different languages, the deaf students feel difficult in pronouncing and understanding the vocabularies (datum D1-D17). The reason is clear because many words in English are different in pronunciation with the written form. This condition is worse if the teacher is only using lip-reading as the communication method. The deaf students do not understand the unfamiliar words, invisible letters, and the mono-syllabic words (Bruhn, 1915).

\section{CONCLUSION}

Deaf students use several communication methods in communicating with the teacher and their peers. Those communication methods are sign language, lip-reading, finger-spelling, and Tadoma. Sign language is mostly used during the class while lip-reading and finger-spelling are used as the addition for sign language. Lip-reading is rarely used because the deaf students are difficult to understand English in lip-reading. However, they can understand lipreading if the speaker uses Bahasa Indonesia. Tadoma is rarely used and the teacher uses this method only for pronouncing words.

In using those communication methods, makes the deaf students have several abilities and difficulties in learning English as the foreign language. The abilities are deaf students can pronounce familiar words, answering question that is repeated in each meeting, and understand several familiar vocabularies. However, the deaf students have more difficulties in learning English using lip-reading. Those are pronouncing words and understanding vocabularies. Most of the deaf students find difficult in pronouncing words in English. They tend to pronounce the word as in pronouncing word in Bahasa Indonesia. In understanding vocabularies, the deaf students mostly do not understand in noun words. 
Based on this research, there are several recommendations which might be applied. For hearing parents of deaf students, choosing school with trained and skilled teacher is very important. If possible, giving the deaf students sufficient technology that can boost their language skill will be very beneficial. For teacher of deaf students who teaches English as foreign language, the deaf students must have contact with native speaker to improve their pronunciation skill and using picture in teaching vocabularies is a good option. The last is for the next researcher, it would be better if the next research analyze the communication of deaf students in inclusion school where hearing students are in the same class with the deaf students.

\section{REFERENCES}

[1] Bellugi, Ursula \& Klima, Edward D. (1978). Structural Properties of American Sign Language. In Liben, Lynn S (Ed.). Deaf Children: Developmental Perspectives (pp. 43-68). New York: Academic Press, Inc.

[2] Birinci, Fatma Gülengül. (2014). The Effectiveness of Visual Materials in Teaching Vocabulary to Deaf Students of EFL (Bachelor's thesis). Retrieved May $9^{\text {th }}$ from www.openaccess.hacettepe.edu.tr/handle.

[3] Bowe, Frank. (1998). Language Development in Deaf Children. Journal of Deaf Studies and Deaf Education 3 (1), 73-77.

[4] Bruhn, Martha E. (1915). Lip-Reading for The Deaf (Bruhn Lip-Reading System). Boston: P.Nichols \& Son Co.

[5] Carroll, David W. (2008). Psychology of Language ( $5^{\text {th }}$ ed.). California: Thomson Wadsworth.

[6] Chaer, Abdul. (2003). Psikolinguistik Kajian Teoretik. Jakarta: Rineka Cipta.

[7] Deaf Children Australia. (2012). Language Development and Deaf Children. Retrieved November $22^{\text {nd }} 2016$ from https://deafchildrenaustralia.org.au/wp-content/uploads/2014/11/Language-Development-and-Deaf-Children-2012-v21.pdf\&ved=0ahUKEwityY3FrYjTahUBuZQKHdAIAxAQFggeMAA\&usg=AFQjCNH_u1aDbPqcwef8TbkykPearTvyg\&sig2 $=4 \mathrm{zKCoY2akLdsM15CUkazNw}$.

[8] Doleżalova, Marie. (2013). An English Quest: An Art of Teaching English to the Deaf and Hard-of-Hearing Students. In Domagała-Zyśk, Ewa (Ed.). English as a Foreign Language for Deaf and Hard-of-Hearing Persons in Europe (pp. 153-162). Lublin: Wydawnictwo KUL.

[9] Domagała-Zyśk, Ewa. (2015). Learning and Teaching Strategies in English as a Foreign Language Classes for the Deaf and Hard-of-Hearing Students. John Paul II Catholic University of Lublin, Institute of Pedagogy, Centre of Education of the Deaf and Hard-of-Hearing, 1-6.

[10] Dotter, Franz. (2008). English for Deaf Sign Language Users: Still a Challenge. In Kellet Bidols, C. and Ichse E. Bern, P (Eds.). English in International Deaf Communication (pp. 97-121).

[11] Field, John. (2004). Psycholinguistic: The Key Concepts. The USA and Canada: Routledge.

[12] Gustafson, Marianne. (2008). Pronunciation Strategies for Deaf and Hard of Hearing Students Including Cochlear Implant Users. ASHA $\quad$ Convention. $\quad$ Retrieved $\quad$ May $26^{\text {th }}$ 2017 from https://www.google.co.id/url?sa=t\&source=web\&rct=j\&url=http://www.asha.org/Events/convention/handouts/2008/2002_Gust afson_Marianne/\&ved=0ahUKEwjivZy4tKTUAhWHtpQKHeKpAscQFggbMAA\&usg=AFQjCNFWg5DrGKvjYOWHvd2Niq QCBLMurg\&sig2=ko8rIxJzNWQbNd28wn-B8A.

[13] Hassanat, Ahmad B.A. (2011). Visual Speech Recognition. In Ipsic, Ivo (Ed.). Speech and Language Technologies (pp.279302). Croatia: InTech.

[14] H.P, Achmad \& Abdullah, Alek. (2012). Linguistik Umum. Jakarta: Erlangga

[15] Herman, Ros \& Morgan, Gary. (2011). The Impact of Communication Disability Across the Lifespan. In Hilari, Katerina \& Botting, Nicola (Eds.). Deafness, Language, and Communication (pp. 101-121). Guildford: J\&R Press.

[16] Hernawati, Tati. (2007). Pengembangan Kemampuan Berbahasa dan Berbicara Anak Tunarungu. JASSI 7 (1), $101-110$.

[17] Humphries, Tom., Kushalnagar, Poorna., Mathur, Gaurav., Napoli, Donna Jo., Padden, Carol.,\& Rathmann, Christian. (2014). Ensuring Language Acquisition for Deaf Children: What Linguists can Do. Language 90 (2), e31-e52.

[18] Humphries, Tom., Kushalnagar, Poorna., Mathur, Gaurav., Napoli, Donna Jo., Padden, Carol. Rathmann, Christian., \& Smith, Scott R. (2012). Language Acquisition for Deaf Children: Reducing the Harms of Zero Tolerance to the Use of Alternative Approaches. Harm Reduction Journal 9 (16), 1-9.

[19] Indah, Rohmani Nur \& Abdurrahman. (2008). Psikolinguistik: Konsep dan Isu Umum. Malang: UIN Malang Press.

[20] Liben, Lynn S. (1978). Structural Properties of American Sign Language. In Liben, Lynn S (Ed.). Deaf Children: Developmental Perspectives (pp. 3-20). New York: Academic Press, Inc.

[21] Malloy, Tiara V. (2003). Sign Language Use for Deaf, Hard of Hearing, and Hearing Babies: The Evidence Supports it. American Society for Deaf Children, 1-28.

[22] Marschark, Marc. (2001). Language Development in Children Who Are Deaf: A Research Synthesis. Virginia: FORUM.

[23] Meier, Richard P. (1991). Language Acquisition by Deaf Children. American Scientist 79 (1), 60-70.

[24] Mellon, Nancy K., Niparko, John K., Rathmann, Christian., Mathur Gaurav., Humpries, Tom., Napoli, Donna Jo., Handley, Theresa., Scambler, Sasha and Lantos, John D. (2015). Should All Deaf Children Learn Sign Language?. PEDIATRICS 136, (1), 170-176.

[25] Moores, Donald F. (1997). Psycholinguistics and Deafness. American Annals of the Deaf 142 (3), 80-89.

[26] Moritz, Nuzha. (2016). Oral Communication and Intelligibility in Deaf Speech. In Domagała-Zyśk, Ewa and Kontra, Edit H (Eds.). English as Foreign Language for Deaf and Hard-of-Hearing Persons: Challenges and Strategies (pp. 9-22). Cambridge: Cambridge Scholars Publishing.

[27] Office for Public Management. (2015). Research into the Deaf Audience in the UK: Final Report to the British Sign Language Broadcasting Trust. London: OPM.

[28] Ogden, Richard. (2009). An Introduction to English Phonetics. Edinburgh: Edinburgh University Press.

[29] Plotnik, Rob. (2005). Introduction to Psychology. California: Wadsworth Thomson Learning. 
[30] Pritchard, Pat. (2013). Teaching of English to Deaf and Severely Hard-of-Hearing Pupils in Norway. In In Domagała-Zyśk, Ewa (Ed.). English as a Foreign Language for Deaf and Hard-of-Hearing Persons in Europe (pp. 113-134). Lublin: Wydawnictwo KUL.

[31] Reed, Charlotte. (n.d). The Implications of the Tadoma Method of Speechreading for Spoken Language Processing. Research Laboratory of Electronics. Cambridge: Massachussets Institute of Technology.

[32] San Diego State University (SDSU) Library. (n.d). Lip Reading: Slides and Study Notes. Retrieved February $20^{\text {th }} 2017$ from http://www-rohan.sdsu.edu/ boothro/nas/Lipreading/Lipreading\%2520slides\%2520and\%2520notes.pdf\&ved=0ahUKEwisK3Ds4jTAhXEmpQKHZeNDWAQFggZMAA\&usg=AFQjCNFvlM120oRJenxAXaf06j6Bi10qdQ\&sig2=jkm8Oplh1OIBvFYy6AsQ.

[33] Steinberg, Danny D and Sciarini, Natalia V. (2006). An Introduction to Psycholinguistics. Harlow: Pearson Education Limited.

[34] Szymanski, Christen., Lutz, Lori., Shahan, Cheryl and Gala, Nicholas. (2013). Critical Needs of Students Who are Deaf or Hard of Hearing: A Public Input Summary. Washington D.C: Laurent Clerc National Deaf Education Center.

[35] Talha, Kamil S., WAN, Khairunizam., Razlan, Zuradzman Mohamad and Shariman. (2016). Speech Analysis Based On Image Information from Lip Movement. $5^{\text {th }}$ International Conference on Mechatronics (ICOM’ 13) (53), 1-18.

[36] United Nations Educational, Scientific, and Cultural Organizations. (2000). Deafness: A Guide for Parents, Teachers and Community Workers. Retrieved November $22^{\text {nd }} 2016$ from www.unesco.org/education/educprog/sne.

[37] Victorian Deaf Society. (2010). Speechreading (Lipreading)-Visual Cues (04). Victoria: Victorian Deaf Society.

[38] Warren, Paul. (2013). Introducing Psycholinguistics. Cambridge: Cambridge University Press.

[39] Wasito, Dian R., S. Sarwindah, Dwi., \& Sulistiani, Wiwik. (2010). Penyesuaian Sosial Remaja Tuna Rungu yang Bersekolah di Sekolah Umum. INSAN 12, 138-152.

[40] Widia, Yunita Ayu. (2013). Pemerolehan Kosakata Anak Tunarungu Berdasarkan Kelas Kata Bahasa Indonesia di SDLB Karya Mulia II Surabaya: Kajian Psikolinguistik. Skriptorium 1, 129-142.

[41] World Health Organization. (2016). Childhood Hearing Loss. Retrieved September $20^{\text {th }} 2016$ from www.who.int/pbd/deafness/world-hearing-day/en.

[42] Yule, George. (2010). The Study of Language. Cambridge: Cambridge University Press.

Rohmani Nur Indah is a lecturer of English Language and Letters Department and the editorial chief of El Harakah Journal on Islamic Culture at UIN Malang. She earned her doctorate in English Language Teaching from State University of Malang, East Java, Indonesia. Her research concerns on psycholinguistics, writing skills, critical thinking, and autism.

Chanastalia is a bachelor of English Letters Department of Universitas Islam Negeri Malang. Her research interest covers psycholinguistics and special education. 